\title{
Analysis of the Links between Burnout Syndrome and Coping Strategies in Trade Managers
}

\author{
Zuzana Birknerová ${ }^{1}$, Barbara Nicole Čigarská ${ }^{2 *}$ \\ ${ }^{1,2}$ Faculty of Management, Department of Managerial Psychology, University of Prešov, Prešov, Slovakia
}

\begin{abstract}
Keywords:

Burnout syndrome,

Burden on managers,

Trade managers, Coping strategies

Received

29 March 2021

Received in revised form

14 April 2021

Accepted

17 April 2021

*Correspondence:

barbara.nicole.cigarska@smail.unipo.sk

Burnout syndrome presents the main problem in the mental and physical state. It is one of the most studied work-related syndromes in recent decades, and it is closely related to energy depletion, exhaustion, chronic stress from work that is not wellmanaged. The matter commonly points to health specialists, but it is necessary not to be indifferent in other professions. Depending on the purpose of the research, the following methodologies were applied. The Maslach Burnout Inventory (MBI) comprised of twenty-two issues relating to determinants of Emotional Exhaustion (EE), Depersonalization(DP), and Personal Accomplishment (PA), and the Brief Cope Inventory (COPE) was used to find out what coping strategies trade managers choose in demanding situations. This self-report questionnaire contains the scale that defines an individual's primary coping styles: Avoidant or Approach Coping. The main goal of the study was an analysis of associations between burnout syndrome determinants and coping strategies in trade managers $(\mathrm{N}=270)$. The data were collected in the Slovak Republic by online questionary, and the representative sample involved top managers $(\mathrm{N}=57)$, middle managers $(\mathrm{N}=120)$, and first-level managers $(N=93)$. The analysis confirmed the existence of statistically significant links between selected determinants of burnout syndrome and certain coping strategies in terms of demanding situations in trade managers. Based on the outcomes, it can be summed up that managers used Approach coping strategies more often than Avoidance coping strategies.

(c)CIKD Publishing
\end{abstract}

Burnout can affect anyone of us, and what is more, certain differences are noticeable in its occurrence, especially personality traits and managers' behavior. We chose to focus on this matter since it is confounded with other factors, such as occupation, educational background, social roles, expectations, or even political or economic realities (Maslach \& Leiter, 2008). Some publications regarding the burnout syndrome phenomenon are grounded on specific professions (Galdino, 
Martins, Haddad, Robazzi, \& Birolim, 2016; Maslach, Christina, \& Leiter, 2016; Schaufeli, Leiter, $\&$ Maslach, 2009). There exist few population-based reports that deal with the impact of gender, work, family, social support, marital status, and additional factors of life (Etzion, 1984; Farshi \& Omranzadeh, 2014; Kiş, 2014; Theorell et al., 2014; Velando-Soriano et al.,2020; Wharton, 2013).

In the results, it is appropriate to draw attention to the weaknesses resulting from available research in assessing determinants of burnout syndrome in the context of using strategies to manage difficult situations in managerial work in the field of business. The benefit of the present study is a summarization of investigated phenomenon through correlation analysis. This study examines if the proper stress management strategies can help to eliminate burnout syndrome.

Theorell, Emdad, Arnetz, and Weingarten (2001) discovered that a one-year psychological program was beneficial for managers regarding reduced stress levels. Their study analyzed the reinforcement of behavior of managers concerning low levels of stress. Prottas (2008) described that if managers acted honestly, it was positively associated with their work fulfillment and lower anxiety levels. On the contrary, Yagil (2006) found that if a manager manifests rude behavior related to stress, it results in a higher rate of burnout syndrome.

\section{Burnout Syndrome in Trade Managers in terms of General Theoretical Views}

There is no regularized classification of burnout syndrome; even so, generally accepted and widespread is that burnout syndrome is the phenomenon known as a tridimensional psychological syndrome (Maslach, Schaufeli, \& Leiter, 2001). The term burnout syndrome was first originated in 1974 by psychoanalyst Herbert Freudenberger, which led to psychologists' enormous interest (Freudenberger, 1974). Later he wrote the book called Burnout: The High Cost of High Achievement, there the syndrome is described as the destruction of motivation or enticement, especially when dedication does not bring desired results (Freudenberger \& Richelson, 1985, as cited in Scott, 2020). Burnout portrays a condition of emotional, psychological, and mental drowsiness that is triggered by extreme and sustained burdens. As prolonged stress continues, the individual starts to lose interest, motivation, energy, productivity and starts to feel helpless, cynical, resentful, or hopeless (Smith, 2020). Distancing psychologically (Depersonalization) from coworkers, employees, or clients is a work-strain (Semmer, McGrath, \& Beehr, 2005). Work stress can be similarly demarcated as an emotional mismatch among job demands and capabilities of workers. Also, it has been named an occupational hazard (Schub, 2018). Work stress and afterward stages of burnout generate a so-called neuroendocrine reaction that leads to another physiological response contributing to mental and physical disorders. Possible aftermath of inveterate work pressure and resulting burnout involve migraine headache, insomnia, irritable bowel syndrome, hypertension, muscle tension, and frequent cardiovascular diseases (Hayes, Douglas, \& Bonner, 2015). It predominantly disturbs individuals who are very ambitious, capable, and responsible, often used to put the greatest effort into work or passion, usually recognized as perfectionists (Carter, 2013). While relationships among coping, stress, and perfectionism are somewhat consistent in literature, the connection between burnout syndrome and perfectionism is considered to be more clouded (Fye, Cook, Baltrinic, \& Baylin, 2020).

Proper leadership abilities may build a positive influence on burnout syndrome. A concept of contemporary leadership proposes the idea that leaders are made, not born. The investment in leadership development and the issue of burnout syndrome would not be ignored since healthcare organizations struggle to delineate and provide serious health care (Hamade, Aoun, Zimmerman, $\&$ Bendok, 2015). Although no particular studies have focused on entrepreneurs, there exist several 
stats or research papers concerning the rise of burnout syndrome and depression among the workers. Factors such as too long screen time and hours of work, poor personal interactions, pollution of the air, poor food quality, feelings of a total loss of meaning in professional life often contribute to it (Beck et al., 2011; Koutsimani, Montgomery, \& Georganta, 2019). Research papers appear to distinguish between existential and circumstantial types of burnout. The first one is based on the loss of meaning in professional life, poorer communication with clients, colleagues, or employees, low sympathy for professional identity, lack of self-affirmation. The second one is based on workplace requirements, disrespect for personal life, or not making time off (Ghanimeh, 2019). A report about professional identity, burnout syndrome, and work in managers investigated the argument that a weak confirmation of the professional identity of managers is linked with a higher stage of burnout syndrome. Conclusions showed a critical connection between the syndrome and an inadequate confirmation of specific professional identity standards, mostly gratitude and work requirements (Hamouche \& Marchand, 2021). These findings increase the significance of associations between demands of managers' work and stress that causes mental exhaustion.

\section{Coping in Trade Managers in terms of a General Theoretical View}

Coping strategies characterize cognitive and behavioral strategies used to control strains, crises, and conditions that are assessed as disturbing (Carr \& Pudrovska, 2007). There exist two general categories of coping. At first, problem-focused coping strategies are perceived as much more productive and involve a direct effort to modify stressors from the external environment. Second, emotion-focused strategies are constituted as less effectual since it involves changing appraisals of the individual to disregard the inevitability of taking actions (Lazarus \& Folkman, 1987) or decreasing and managing the emotional distress which grades from the crisis (Carr \& Pudrovska, 2007). To put it another way, coping can refer to reasoning and acting that people use to accomplish specific demanding situations and emotions (Janney, 2017). Emotional management can be utilized in a broader range of conditions. For instance, regulation of emotions may include managing positive emotional reactions such as smiling while we meet somebody, but coping strategies are restrained by reactions to stressors (Compas et al., 2020). Coping strategies are linked with decreasing undesirable emotions, intensifying of perception of optimistic emotions, and empowering adaptable responses of people (Carlson et al., 2015). For example, emotion-focused strategies of coping incorporate self-blaming, positive reassessment, or venting. Positive reassessment means an adaptive self-regulatory strategy focused on emotions linked to insignificant pessimistic impacts (Garnefski \& Kraaji, 2006). The application of strategies focused on emotions can improve self-adaptation; besides, these strategies increase the self-confidence and capability to overcome potential difficulties (Bisri, Karsiyanto, Zahra, \& Chusniyah, 2021).

From the literature studied so far, we have found out that coping may be rationalized as persistently changing determination of cognitive and also behavioral personality to regulate specific external or internal requests considered as demanding or exceeding the strength of the individual (Janney, 2017). Prior studies have surveyed relationships between employee burnout and styles of leadership. It was detected that styles of leadership are determined by competence to implement ethical or compassionate problem-solving attitudes, sympathize with workforces or collaborators, by the ability of a leader to participate in active listening, communication, the ability to reveal willingness and receive recommendations associated with a lower prevalence of burnout syndrome (Kelly \& Hearld, 2020). The study about the relationship between leadership procedures and the working life of managers revealed the importance of a transformational leadership style. It 
consisted of empowering leaders to use suitable methods to address the accurate level of control and relevance of remuneration to optimistically affect a manager's gratification (Lee \& Cummings, 2008). Although directors do not place requirements on workers outside of business hours, they can barely reach a psychological rest, generally when they realize that a manager may get in touch with them at any moment. It is beneficial when managers notice symptoms of anxious employees, as unfinished activities, reduced productivity, diminished quality of work, or missteps (Wilkie, 2020). All issues generate a working strain and a final stage of burnout syndrome often incorporate handling with a high level of personal stress, conflicts with colleagues and family members, a dissatisfaction with work-life balance, exceeding workload, uncertainty in life, violence, or abuse from colleagues, clients, ambiguity or role conflict, sometimes insufficient access to education (Cañadas-De la Fuente et al., 2015).

\section{The Study}

This study examines whether there are positive relations between the assessment of individual determinants of burnout syndrome in trade managers (MBI methodology) and the assessment of selected strategies of managerial behavior in challenging situations of a business sphere (Brief COPE methodology). In the hypothesis, we presumed that there are positive relationships between the assessment of individual determinants of burnout syndrome of trade managers and the assessment of selected strategies of the behavior of managers in difficult situations of managerial occupation. The present study attemts to enrich a field of knowledge associated with a psychological concern related to trade managers in terms of burnout, to find out whether certain coping strategies influence the formation of burnout syndrome or prevent it by the selection of the appropriate strategy, as well as to detect the existence of associations among determinants of burnout syndrome and coping strategies in terms of trade managers. The study assessed the risks of burnout syndrome and described what coping strategies are used among trade managers. It seeks to inform about the role and influence of healthy emotions and the ability to use different coping strategies. From this extensively accepted transactional attitude, coping could be expressed by behavioral and cognitive efforts engaged in reaction to internal and external requirements that an individual considers as a threat to his welfare (Freire et al., 2020). The criterion for evaluating the effectiveness of a used strategy is its contribution to the mitigation of expressions or impacts of burden, or its complete elimination while maintaining the work post of the affected individual (Vitková \& Zábrodská, 2014).

\section{Method}

\section{The Sample}

The research sample consisted of 270 trade managers aged from 23 to 51 years $(M=40.93, S D=$ $8.12)$, managerial length of practice from 2 to 24 years $(M=11.58, S D=6.35)$. Of these, 108 $(40.0 \%)$ female trade managers and $162(60.0 \%)$ male trade managers from Slovakia participated in the study. As presented in Table 1, the data were collected online in the Slovak Republic to obtain a representative sample of top managers $(57,21.1 \%)$, middle managers $(120,44.4 \%)$, firstlevel managers $(93,34.4 \%)$. The statistical software SPSS 22 was used for data processing. 
Table 1

Inclusion of Managers in the Organization

\begin{tabular}{lcccc}
\hline & Frequency & Percent & Valid percent & Cumulative percent \\
\hline Top managers & 57 & 21.1 & 21.1 & 21.1 \\
Middle managers & 120 & 44.4 & 44.4 & 65.6 \\
First level managers & 93 & 34.3 & 34.3 & 100.0 \\
total & 270 & 100.0 & 100.0 & \\
\hline
\end{tabular}

\section{Measures}

\section{The Maslach Burnout Inventory (MBI)}

It serves to measure the degree of burnout of individuals who work with other people. It stands for a 22-question survey covering aspects characterized as the main determinants or dimensions of burnout: Emotional Exhaustion (EE), Depersonalization (DP), Personal Accomplishment (PA). Trade managers had an opportunity to choose on the Likert scale from the following frequency rating options, 0 - never, 1 - several times per year, 2 - once a month, 3 several times per month, 4 - weekly, 5 - several times per week, 6 - daily. If individuals have high EE values (a score of 27 and higher) or DP values (a score of 10 and higher), they present at least one symptom of burnout. As the alternative approach, the individuals who have high EE values plus either low PA values or high DP values are considered to suffer burnout. Only one determinant is considered a positive indicator: Personal Accomplishment (a score less than 33), and others are considered negative indicators: Depersonalization and Emotional Exhaustion. Evidence implies that high scores of EE and DP differentiate between non-burned-out individuals and clinically burnout individuals (Schaufeli, Bakker, Hoogduin, Schaap, \& Kladler, 2001) since an approach classifies those whose level of burnout syndrome is evaluated as a risk of too serious professional and personal consequences (Dyrbye et al., 2010).

\section{The Brief-COPE Inventory}

A self-report questionary comprised of 28 questions that measure ineffective and effective methods to cope with challenging situations. It was developed as a short version of the original 60-item scale (Carver, Scheier, \& Weintraub, 1989). It was used to determine what coping strategies trade managers choose in demanding situations and how they act to deal with the burden. It outlines fourteen approaches about how to cope with uncomfortable and stressful situations. The scale determines an individual's primary coping styles as either Avoidant Coping or Approach Coping. In this study, the scale applies to the coping style of trade managers in severe situations. The 28 questions involve a four-point scale of answers, 0 - I have not been doing this at all, 1 - I have been doing this sometimes, 2 - I have been doing this often, 3 - I have been doing this a lot. The items are divided into fourteen subscales, and every subscale is characterized by two questions dealing with a certain strategy. Managers were asked how often they choose a certain coping strategy to deal with a stressful situation and which coping strategies are the most typical. It was evident that Avoidant Coping (substance use, behavioral disengagement, denial, venting, selfdistraction, self-blame) is less effective at managing anxiety than Approach Coping (social support, positive reframing, active coping, acceptance, planning, instrumental support). Coping strategies of Humor and Religion are considered to be neither Avoidance nor Approach.

Based on testing of kurtosis and skewness, the distribution of data can be considered to be normal in terms of the MBI methodology (Table 2) and the Brief COPE methodology (Table 3). 
Table 2

Skewness and Kurtosis of Data Distribution in Individual Determinants of the MBI Methodology

\begin{tabular}{lccc}
\hline & Emotional Exhaustion & Depersonalization & Personal Accomplishment \\
\hline Skewness & .39 & .37 & -.30 \\
Kurtosis & -.41 & .14 & .12 \\
\hline
\end{tabular}

Table 3

Skewness and Kurtosis of Data Distribution in Individual Factors of the Brief COPE Methodology

\begin{tabular}{lcc}
\hline & Skewness & Kurtosis \\
\hline Self-Distraction & .22 & .41 \\
Active Coping & .11 & .07 \\
Denial & .47 & .19 \\
Substance Abuse & .73 & .65 \\
Social Support & .12 & .59 \\
Instrumental Support & .13 & -.42 \\
Behavioral Disengagement & .13 & -.26 \\
Venting & .29 & .27 \\
Positive Reframing & .17 & -.13 \\
Planning & -.21 & -.22 \\
Humor & .67 & .63 \\
Acceptance & -.14 & .15 \\
Religiosity and Spirituality & .50 & -.69 \\
Self-blame & .23 & -.39 \\
\hline
\end{tabular}

The reliability was determined by assessing Cronbach's Alpha. The analysis revealed that both MBI $(\alpha=.82)$ and the Brief COPE Inventory $(\alpha=.85)$ are reliable. The observed values of the Cronbach's alpha coefficient indicate that the inner consistency of the items saturating specified components is within the range of acceptability.

\section{Results}

We assumed that there exist positive and significant relations between determinants of burnout syndrome and coping strategies. The links and data were verified and processed using the Pearson correlation coefficient in the statistical program SPSS 22 (Table 4). The research has shown that managers have experienced symptoms of burnout syndrome since the acquired results of the analysis confirmed the existence of positive correlations between determinants of burnout and coping strategies in terms of trade managers, and all relationships were displayed as significant ( $p$ $<$.001). The results revealed that managers used the Approach coping more often than the Avoidance coping style in terms of handling demanding situations. We consider it a positive foundation since we receive Avoidance coping as an unhealthy (maladaptive) strategy because it aggravates stress without helping individuals deal with stressful matters, e.g., procrastination (Dijkstra \& Homan, 2016).

I. Emotional Exhaustion in trade managers is manifested by a total loss of motivation and lack of strength to perform any activity. Trade managers who have a high score in a determinant of Emotional Exhaustion feel very tired and exhausted almost immediately after the thought of a job or workload. Trade managers experience stress while working with people and tend to become unconcerned with people who attribute problems to them. The assessed determinant of burnout 
syndrome positively correlates with the following stress management strategies. Self-distraction $(r$ $=.42, p<.001$ ), a distraction from a stressor, a strategy of non-engaged behavior, is manifested by managers' tendency to engage in other activities and not to think about the problem which bothers them. Denial ( $r=.31, p<.001$ ), suppression, frustration, is characterized by the fact that trade managers can barely admit that something unpleasant has really happened and repeat to themselves that what is happening now is just not possible. Behavioral Disengagement $(r=.42, p<.001)$, unwillingness to help others, not looking for a way to do something better, is related to managers' tendency to procrastinate, regularly give up trying to achieve what they desire, while gradually losing motivation. Religiosity and spirituality $(r=.39, p<.001)$ positively influence the development of healthy personage and overall integration. It means a positive association with the individual welfare, mental and physical health, work satisfaction of trade managers. Enables managers to face risks or uncertainties with serenity and effectively deal with changes in the intricate world.

II. Depersonalization in trade managers manifests itself as insensitivity and the loss of insensibility towards others and a disorder of subjective experience and alienation from oneself and others. Managers who have a high score in a determinant of Depersonalization, based on many dissociated thoughts and emotions, feel not being themselves. Frequently have a prevailing feeling of being less sensitive to the surrounding. The assessed determinant of burnout syndrome positively correlates with the following coping strategies. Active coping $(r=.35, p<.001)$, are activities closely related to planning and long thinking about how to solve a problem, managers positively consider the situation and apply heuristic methods. They focus all efforts only on doing something about the problem and improving the condition, either by changing themselves or changing the background. Venting ( $r=.46, p<.001$ ), the emotional relaxation, sharing of negative emotions, venting of emotions, it goes on with blaming, anger, disappointment, and grumpiness of trade managers who talk about the negative feelings to eliminate or mitigate them. Planning $(r=.37, p$ $<.001$ ), knowing the priorities, not wasting the own energy encompasses good time management, clarifying the actions of solutions, and taking steps to improve the situation.

III. Personal Accomplishment of trade managers manifests itself as a personal performance that demonstrates previous aspects that influence the overall performance of workers. This progressively appears as poorer work efficiency. Burnout syndrome occurs when one experiences feelings of underestimation or never gets praise, and gradually occurs a feeling of the total loss of motivation. Trade managers with a high score in the determinant of Personal Accomplishment perceive themselves as successful persons who have done many conducive things, have a lot of energy, and feel that people around them make them positive. After doing work necessities hard, they gradually get to the point when they feel that it is very exhausting, and it brings them feelings of futility and dissatisfaction. The assessed determinant of burnout syndrome positively correlates with the following coping strategies. Social support $(r=.58, p<.001)$, good relations essential in the prevention of burnout, manifests itself in trade managers as mental support to obtain whichever feedback and share emotions and as the effort to gain and use understanding and sympathy from others. Instrumental support ( $r=.43, p<.001$ ), executive way of searching for help, asking for advice from the others, the manager takes all responsibility and others advise him and help only partially, shows the ways of possible solving of a problem. Humor $(r=.40, p<.001)$, presents the modern way of diversifying work, the so-called job enrichment, managers try to include it in monotonous activities since it seems to be a pleasant and effective way of cooperation. Acceptance 
( $r=.42, p<.001$ ), accepting that nothing can be changed, and it is pointless to deal with anything else, manifests itself in managers by accepting that something has happened results in the belief about the feelings of helplessness and negative emotional experience.

Table 4

Statistically Significant Relationships between Determinants of Burnout Syndrome and Coping Strategies

\begin{tabular}{|c|c|c|c|c|}
\hline \multirow[t]{2}{*}{ Coping strategies } & & \multicolumn{3}{|c|}{ Determinants of Burnout syndrome } \\
\hline & & Emotional Exhaustion & Depersonalization & $\begin{array}{c}\text { Personal } \\
\text { Accomplishment }\end{array}$ \\
\hline \multirow{2}{*}{ Self-Distraction } & Pearson Correlation & $.42 * *$ & & \\
\hline & Sig. (2-tailed) & .00 & & \\
\hline \multirow{2}{*}{ Active Coping } & Pearson Correlation & & $.35 * *$ & \\
\hline & Sig. (2-tailed) & & .00 & \\
\hline \multirow{2}{*}{ Denial } & Pearson Correlation & $.31 * *$ & & \\
\hline & Sig. (2-tailed) & .00 & & \\
\hline \multirow{2}{*}{ Social Support } & Pearson Correlation & & & $.58^{* *}$ \\
\hline & Sig. (2-tailed) & & & .00 \\
\hline \multirow{2}{*}{ Instrumental Support } & Pearson Correlation & & & $.43^{* *}$ \\
\hline & Sig. (2-tailed) & & & .00 \\
\hline \multirow{2}{*}{$\begin{array}{l}\text { Behavioral } \\
\text { Disengagement }\end{array}$} & Pearson Correlation & $.42 * *$ & & \\
\hline & Sig. (2-tailed) & .00 & & \\
\hline \multirow{2}{*}{ Venting } & Pearson Correlation & & $.46^{* *}$ & \\
\hline & Sig. (2-tailed) & & .00 & \\
\hline \multirow{2}{*}{ Planning } & Pearson Correlation & & $.37 * *$ & \\
\hline & Sig. (2-tailed) & & .00 & \\
\hline \multirow{2}{*}{ Humor } & Pearson Correlation & & & $.40 * *$ \\
\hline & Sig. (2-tailed) & & & .00 \\
\hline \multirow{2}{*}{ Acceptance } & Pearson Correlation & & & $.42^{* *}$ \\
\hline & Sig. (2-tailed) & & & .00 \\
\hline \multirow{2}{*}{ Religiosity } & Pearson Correlation & $.39 * *$ & & \\
\hline & Sig. (2-tailed) & .00 & & \\
\hline
\end{tabular}

\section{Discussion}

The obtained results confirmed statistically significant associations between determinants of burnout syndrome and coping strategies in trade managers. Considering statistically significant links between burnout syndrome and the individual coping strategies used by managers, their usage may be based on high demands on the profession caused by high expansion of knowledge, scientific or technological progress, family demands, etc. Predictors of an individual's successful adaptation to requests of business activity are features of a personal coping behavior that have a moderating influence on stress issues (Voitenko, Kaposloz, Myronets, Zazymko, \& Vasyll, 2021). We agree with the idea that coping strategies are formed under the influence of burnout and professional stress. Still, on the other hand, they signify a desire to fulfill the necessity of self-actualization (Voitenko et al., 2021). We also agree with the results of the study that discuss the importance of including training of assertiveness as another coping strategy since it helps to fight against social anxiety, work exhaustion, and a lack of personal accomplishment (Salazar, Roldán, \& Garrido, 2014). Occupational burnout is defined as a particular category of stress syndrome portrayed by emotional tiredness. Studies have revealed that burnout syndrome is not unusual among individuals with greater work independence, free working regulations, ingenuity, and responsibility 
(Makasheva et al., 2016). Even if people like managers, teachers, or entrepreneurs have bigger freedom in the performance of professional duties, it requires an adequate approach or serious research of employment. This can cause a negative body's reaction to the high work intensity since individuals are out of the professional and the original working atmosphere. Clinical research from Italy has examined whether burnout is a matter only of physicians since this phenomenon is investigated quite often and predominantly among healthcare professionals. The study confirmed weak to moderate correlations with EE and a very high experience of reduced PA among other occupations (Cagnazzo et al., 2021). To put it another way, as several professions require work with people daily, it brings a burden to the mind of business people who tend to be tired and demotivated. Keep in mind that we are unique and, therefore, the symptoms of burnout may vary from person to person. The best way how to perceive burnout is to understand it as a psychological state of exhaustion. As a result, it starts to appear as low work efficiency, loss of motivation, cynicism, etc. Maroon (2012). Burnout syndrome has become a serious problem, and we see that businesspeople and managers suffer from feelings of being angry or alienated, leading to different conflicts. Coping strategies are changing over time since it represents a real effort and specific strategies to manage internal and external pressures. According to Govêia et al. (2018), it is perceived as a character attribute or addictive inclination for the approaching problem. It could influence the way of facing stressors and the expression of anxiety in managers by using ineffective strategies, especially when they suffer depression. At present, there exists information that coping counts and particular strategies work significantly better than others (Britt et al., 2016; Skinner et al., 2003).

Determinant of Emotional exhaustion caused them to resign since they are apathetic, they stopped setting new goals, stopped believing in themselves, lost objective view of reality, did not make decisions based on facts, but on bad feelings, they were unable to cope with everyday difficulties, they concluded that the only solution is to get out of trouble. At the senses of burnout, attitudes were more negative, with the inability to overcome further failure. The great importance for comfort had the phenomena of religion and faith - coping strategy of Religiosity. Cook (2014) indicates that there are combined results on this coping strategy since it includes spirituality and argues that spiritual, but not religious, may not experience protection against depression. Spirituality promotes the spirit of assisting customers and leads to ethical behavior. Spiritual individuals strive to serve and tend to deal with the problems with a greater significant commitment (Ghanizadeh, Ardabili, Kheirandish, Rasouli, \& Hassanzadeh, 2021).

Depersonalization usually includes cynical or negative manners towards others with whom the individuals work. Whereas Depersonalization correlated with a coping strategy of Planning, we assume that managers identified threats, evaluated risks, set planes, approached responsibly to the organization, took into account competencies, scheduled tasks to be stimulating, avoided monotonous work, provided opportunities for social interaction and awareness was the priority, tried to be regularly informed. According to Garnefski and Kraaij (2014), managers who use Active Coping, including positive reconsideration, may be more resilient than those who use strategies as self-blame. The essential was to set practical tools to achieve new goals. Anxiety and depression had a strong influence on professional-managerial performance. Work-related stress had indirect and direct positive effects on anxiety and only the indirect positive effect on depression (Chen et al., 2020). Reduced determinant of Personal Accomplishment referred to declined job satisfaction and a low sense of competence. Improving constructive feedback, supporting opportunities that 
strengthen the importance of contributions, or enabling managerial-only social time may enhance appreciation of the Personal Accomplishment of trade managers. A study from the USA showed that individuals had a higher score in the personal accomplishment after receiving an adequate constructive opinion, good collegial social support, feeling that knowledge and skills they have are important to society (Guenette \& Smith, 2018). The study about the impact of Social support strategy on the growth of burnout proved that better co-worker succor contributes to the prognosis of burnout. It decreases depersonalization and increases personal accomplishment (Greenglass, Burke, \& Konarski, 1997). Enhancing it in the job background would be advantageous to prevent both in managers (Chen et al., 2020). The obvious social support strategy has a moderate function in the reaction to work pressure, but in this case, it does so as the managerial protection factor (Pérez-Fuentes, Molero, Gázquez, \& Soler, 2015). We assume that relationships between coping strategies of social support and instrumental support can be stronger within occupations with higher emotional work demands (Mathieu, Eschleman, \& Cheng, 2019). Social support has been found to mitigate undesirable results of burnout syndrome on health, regardless of the type of gender (Ruisoto et al., 2021).

In connection with burnout syndrome in terms of gender, women are perceived as a higher risk group than men because of a higher burden caused by work responsibilities often parallel with household maintenance and the possible upbringing of kids. We dare to agree that females have to handle a majority of housekeeping, babysitting responsibilities despite increased involvement in full-time occupations (Lyonette \& Crompton, 2015). Household duties are still seen as the main liability of females, and it creates severe burdens to negotiate or balance domestic and work obligations (Craig \& Sawikar, 2009). Differences between females and males in response to stressful situations and cognitive style are significant to understanding gender differences at the beginning of depression (Mazure \& Maciejewski, 2003). Workplace stressors and the levels may create an immense burden not only on women or contribute to the formation of burnout (Aldossari $\&$ Chaudhry, 2020). There exist many correlates of burnout, and researchers explored them at the individual level, the work level, and the organizational level since a range of levels influences the experience of burnout (Dewe, 2004). Based on this, we could understand where the levels have the major effect in the process or how much their effect can be generalized.

\section{Conclusion}

Gaining knowledge and understanding of the issue of management of challenging life events was the main motivation to study the issue of burnout and anxiety. Based on the discussion above and the presented research, we can conclude that the outputs support the necessity of increasing directed prevention and making time for relaxation, hobby, sports, and generally for activities which make people happy not frustrated, particularly in the area of management and trade. At the same time, they indicate the appropriateness of utilizing the MBI and the Brief COPE methodologies to detect connections between expressions of burnout syndrome and chosen coping strategies by trade managers since the resulting severity of a mental and physical condition is an indicator of the original enthusiasm of the individual. Unfortunately, the most enthusiastic people often fall into the most challenging forms of burnout syndrome.

The study contributed to acknowledgment that the phenomenon of burnout is a serious state of extreme exhaustion that brings various psychosomatic problems and a severe decline in performance. We aimed to contribute to the fact that burnout manifests itself in the areas of cognition, motivation, emotions and affects the attitudes, opinions, performance, and therefore 
behavior of people who have already been disturbed by variables that affect the start of this syndrome. We have contributed to the opinion that although we most often encounter burnout in people who work in so-called helping professions, e.g., doctors and health care providers, other individuals are similarly exposed to long-term mental stress. The study emphasizes that burnout syndrome is a well-known phenomenon. It is a medical problem that affects the quality of life of doctors and managers, teachers, students, athletes, artists, officials, and so on. For example, a crosssectional study about burnout in students investigated the prevalence of the syndrome and aimed to classify its predictors. It was found out that $11.6 \%$ of students from 129 doctoral and master students manifested different signs of burnout syndrome. It was mostly a lower perception of social support, dissatisfaction with the study topic, lower leisure opportunities (Galdino, Martins, Haddad, Robazzi, \& Birolim, 2016). Since the signs of burnout syndrome occur already in young people, like in the study sample, we may assume that burnout syndrome could be considered a threat to our society if individuals and societies do not care early about their mental well-being.

The study included a quite specific sample. It will be noteworthy to imitate the findings in other work-related groups since we assume that the relevance of the matter becomes evident in other occupational groups confronting high emotional demands and high workload. We propose implementing meta-analyses where multiple scientific studies would address the same issue, providing much more reliable conclusions than the mentioned studies.

\section{Implications}

There are situations when trade managers need support, help, adjustment of work conditions, and strengthening of competencies to solve problems related to the performance of the profession. We suggest at least to think about talking to a mental health provider or a doctor since symptoms may be related to burnout syndrome, e.g., dragging yourself to work, having the constant feeling of lacking energy, having trouble getting started, disturbing sleeping habits, lacking satisfaction from any achievement, feeling disillusioned about work, usage of drugs or alcohol to feel better, etc. (Shanafelt \& Noseworthy, 2017). Moreover, trade managers may improve their existence at work through practices of transformational leadership focused on the amount of correctness of rewards, control, satisfaction to influence the job gratification (Lee \& Cummings, 2008). It is necessary to find your resources or perspectives when overcoming difficult situations, create an adequate workload, ensure a sufficient number of staff, reduce and delegate administrative activities, or select quality employees. Highly advised is to strengthen the occupational programs to minimize the effects of hazardous work conditions, which support the development of burnout and formation of different long-term and mid-term health complaints (Useche et al., 2019). A direct prescription or standard treatment for burnout does not exist, and prevention is the best cure that may strengthen organizational performance and managers' lives (Brown \& Quick, 2016). We suggest preventive coping strategies to stop thinking negatively about yourselves as soon as possible, try to avoid any form of technologies and just relax by being offline from e-mails, also be grateful for the simplest things in life since we believe that the development of a sense of gratitude brings a better mood, more energy and individuals may feel much better. 


\section{Acknowledgment}

This paper was financed and supported by the scientific grant project GaPU 30/2020 - Grant Agency for Doctoral Students and Young Researchers of the University of Prešov in Prešov. This paper is a result of project 012PU-4/2020 KEGA: Trading Behavior - Creation of the subject and textbook for non-economic study programs.

\section{References}

Aldossari, M., \& Chaudhry, S. (2020). Women and burnout in the context of a pandemic. Gender, Work, and Organization, 1-9. https://doi.org/10.1111/gwao.12567

Beck, A., Crain, A. L., Solberg, L. I., Unützer, J., Glasgow, R. E., Maciosek, M. V., \& Whitebird, R. (2011). Severity of depression and magnitude of productivity loss. Annals of Family Medicine, 9(4), 305-311. https://doi.org/10.1370/afm.1260

Bisri, M., Karsiyanto, P. A. A., Zahra, A. C. A., \& Chusniyah, T. (2021). Emotion-focused coping strategies as predictors of new inmates' adjustment in the pandemic era. KnE Social Sciences, 21-31. https://doi.org/10.18502/kss.v4i15.8186

Britt, T. W., Crane, M., Hodson, S. E., \& Adler, A. B. (2016). Effective and ineffective coping strategies in a low-autonomy work environment. Journal of Occupational Health Psychology, 21(2), 154-168. https://doi.org/10.1037/a0039898

Brown, L. W., \& Quick, J. C. (2016). Workplace health. In H. S. Friedman (Ed.), Encyclopedia of mental health (second edition) (pp. 387-394). Academic Press. https://doi.org/10.1016/B978-0-12-397045-9.00226-3

Cagnazzo, C., Filippi, R., Zucchetti, G., Cenna, R., Taverniti, C., Guarrera, A. S. E., ... \& Fagioli, F. (2021). Clinical research and burnout syndrome in Italy - only a physicians' affair? Trials, 22(1), 205. https://doi.org/10.1186/s13063-021-05158-Z

Cañadas-De la Fuente, G. A., Vargas, C., San Luis, C., García, I., Cañadas, G. R., \& Emilia, I. (2015). Risk factors and prevalence of burnout syndrome in the nursing profession. International journal of nursing studies, 52(1), $240-249$. https://doi.org/10.1016/j.ijnurstu.2014.07.001

Carlson, E., Saarikallio, S., Toiviainen, P., Bogert, B., Kliuchko, M., \& Brattico, E. (2015). Maladaptive and adaptive emotion regulation through music: a behavioral and neuroimaging study of males and females. Frontiers in Human Neuroscience, 9(466), 1-13. https://doi.org/10.3389/fnhum.2015.00466

Carr, D., \& Pudrovska, T. (2007). Mid-life and later-life crises. In J. E. Birren (Ed.), Encyclopedia of Gerontology (Second Edition) (pp. 175-185). Elsevier. https://doi.org/10.1016/B0-12-370870-2/00126-8

Carter, S. B. (2013, November 26). The tell-tale signs of burnout. Do you have them? Psychology Today. Retrieved from http://www.psychologytoday.com/blog/high-octane-women/201311/the-tell-tale-signs-burnout-do-you-have-them

Carver, C. S., Scheier, M. F., \& Weintraub, J. K. (1989). Assessing coping strategies: A theoretically based approach. Journal of Personality and Social Psychology, 56(2), 267-283. https://doi.org/10.1037/0022-3514.56.2.267

Chen, J., Li, J., Cao, B., Wang, F., Luo, L., \& Xu, J. (2020). Mediating effects of self-efficacy, coping, burnout, and social support between job stress and mental health among young Chinese nurses. Journal of Advanced Nursing, 76(1), 163-173. https://doi.org/10.1111/jan.14208

Compas, B. E., Jaser, S. S., Dunbar, J. P., Watson, K. H., Bettis, A. H., Gruhn, M. A., \& Williams, E. K. (2020). Coping and emotion regulation from childhood to early adulthood: Points of convergence and divergence: Coping and emotion regulation from childhood to adulthood. Australian Journal of Psychology, 66(2), 71-81. https://doi.org/10.1111/ajpy.12043

Cook, C. C. H. (2014). Suicide and religion. The British Journal of Psychiatry: The Journal of Mental Science, 204, $254-255$. https://doi.org/10.1192/bjp.bp.113.136069

Craig, L., \& Sawrikar, P. (2009). Work and family: How does the (gender) balance change as children grow? Gender, Work, and Organization, 16(6), 684-709. https://doi.org/10.1111/j.1468-0432.2009.00481.x

Dewe, P. (2004). Job stress and burnout. In C. D. Spielberger (Ed.), Encyclopedia of applied psychology (pp. 475-483). Elsevier. https://doi.org/10.1016/B0-12-657410-3/00442-6

Dijkstra, M. T. M., \& Homan, A. C. (2016). Engaging in rather than disengaging from stress: Effective coping and perceived control. Frontiers in Psychology, 7, 1415. https://doi.org/10.3389/fpsyg.2016.01415

Dyrbye, L. N., Massie, F. S., Jr, Eacker, A., Harper, W., Power, D., Durning, S. J., ...Shanafelt, T. D. (2010). Relationship between burnout and professional conduct and attitudes among US medical students. JAMA: The Journal of the American Medical Association, 304(11), 1173-1180. https://doi.org/10.1001/jama.2010.1318 
Etzion, D. (1984). Moderating effect of social support on the stress-burnout relationship. Journal of Applied Psychology, 69(4), 615-622. https://doi.org/10.1037/0021-9010.69.4.615

Farshi, S. S., \& Omranzadeh, F. (2014). The effect of gender, education level, and marital status on Iranian EFL teachers' burnout level. International Journal of Applied Linguistics \& English Literature, 3(5), 128-133. https://doi.org/10.7575/aiac.ijalel.v.3n.5p.128

Freire, C., Ferradás, M. D. M., Regueiro, B., Rodríguez, S., Valle, A., \& Núñez, J. C. (2020). Coping strategies and self-efficacy in university students: A person-centered approach. Frontiers in Psychology,11(841), 1-11. https://doi.org/10.3389/fpsyg.2020.00841

Freudenberger, H. J. (1974). Staff burn-out. The Journal of Social Issues, 30(1), 159-165. https://doi.org/10.1111/j.15404560.1974.tb00706.x

Freudenberger, H. J., \& Richelson, G. (1985). Burnout: The high cost of high achievement. London, England: Arrow Books.

Fye, H. J., Cook, R. M., Baltrinic, E. R., \& Baylin, A. (2020). Examining individual and organizational factors of school counselor burnout. The Professional Counselor, 10(2), 235-250. https://doi.org/10.15241/hjf.10.2.235

Galdino, M. J. Q., Martins, J. T., Haddad, M. do C. F. L., Robazzi, M. L. do C. C., \& Birolim, M. M. (2016). Síndrome de Burnout entre mestrandos e doutorandos em enfermagem. Acta Paulista de Enfermagem, 29(1), 100-106. https://doi.org/10.1590/19820194201600014

Garnefski, N., \& Kraaij, V. (2006). Relationships between cognitive emotion regulation strategies and depressive symptoms: A comparative study of five specific samples. Personality and Individual Differences, 40(8), 1659-1669. https://doi.org/10.1016/j.paid.2005.12.009

Garnefski, N., \& Kraaij, V. (2014). Bully victimization and emotional problems in adolescents: moderation by specific cognitive coping strategies? Journal of Adolescence, 37(7), 1153-1160. https://doi.org/10.1016/j.adolescence.2014.07.005

Ghanimeh, G. (2019, May 16). Understanding entrepreneurial burnout (and how to deal with it). Retrieved February 28, 2021, from Entrepreneur Middle East website: https://www.entrepreneur.com/article/333631

Ghanizadeh, S., Ardabili, F. S., Kheirandish, M., Rasouli, E., \& Hassanzadeh, M. (2021). Ambidexterity in public organizations with an emphasis on managers' psychological capital. International Journal of Organizational Leadership, 10(1), $72-88$. https://doi.org/10.33844/ijol.2021.60518

Govêia, C. S., Cruz, T. T. M. D., Miranda, D. B. D., Guimarães, G. M. N., Ladeira, L. C. A., Tolentino, F. D., ... \& Magalhães, E. (2018). Association between burnout syndrome and anxiety in residents and anesthesiologists of the Federal District. Brazilian Journal of Anesthesiology (English Edition), 68(5), 442-446. https://doi.org/10.1016/j.bjane.2018.02.006

Greenglass, E. R., Burke, R. J., \& Konarski, R. (1997). The impact of social support on the development of burnout in teachers: Examination of a model. Work and Stress, 11(3), 267-278. https://doi.org/10.1080/02678379708256840

Guenette, J. P., \& Smith, S. E. (2018). Burnout: Job resources and job demands associated with low personal accomplishment in United States radiology residents. Academic Radiology, 25(6), 739-743. https://doi.org/10.1016/j.acra.2017.12.002

Hamade, Y. J., Aoun, R. J. N., Zimmerman, R. S., \& Bendok, B. R. (2015). The modern neurosurgical leader as a cure for team burnout. Neurosurgery, 77(2), N13. https://doi.org/10.1227/01.neu.0000467292.26010.c3

Hamouche, S., \& Marchand, A. (2021). Occupational identity, work, and burnout among managers: Do high performance human resource management practices play a moderator role? Journal of Workplace Behavioral Health, 1-22. https://doi.org/10.1080/15555240.2021.1877553

Hayes, B., Douglas, C., \& Bonner, A. (2015). Work environment, job satisfaction, stress and burnout among haemodialysis nurses. Journal of Nursing Management, 23(5), 588-598. https://doi.org/10.1111/jonm.12184

Janney, J. (2017). Gender Differences when Coping with Depression (University of North Carolina at Pembroke). Retrieved from https://libres.uncg.edu/ir/uncp/f/Jerica\%20Janney\%20Senior\%20Project.pdf

Kelly, R. J., \& Hearld, L. R. (2020). Burnout and leadership style in behavioral health care: A literature review. The Journal of Behavioral Health Services \& Research, 47(4), 581-600. https://doi.org/10.1007/s11414-019-09679-z

Kış, A. (2014). Marital status differences in burnout among educational stakeholders: A meta-analysis. International Journal of Human Sciences, 11(2), 543-558. https://doi.org/10.14687/ijhs.v11i2.2922

Koutsimani, P., Montgomery, A., \& Georganta, K. (2019). The relationship between burnout, depression, and anxiety: A systematic review and meta-analysis. Frontiers in Psychology, 10, 284. https://doi.org/10.3389/fpsyg.2019.00284

Lazarus, R. S., \& Folkman, S. (1987). Transactional theory and research on emotions and coping. European Journal of Personality, 1(3), 141-169. https://doi.org/10.1002/per.2410010304

Lee, H., \& Cummings, G. G. (2008). Examining relationships between director leadership practices and manager worklife and burnout. Journal of Leadership Studies, 2(2), 47-62. https://doi.org/10.1002/jls.20061

Lyonette, C., \& Crompton, R. (2015). Sharing the load? Partners' relative earnings and the division of domestic labour. Work, Employment \& Society: A Journal of the British Sociological Association,29(1), 23-40. https://doi.org/10.1177/0950017014523661 
Makasheva, N., Makasheva, J., Gromova, A., Ishtunov, S., \& Burykhin, B. (2016). The problem of professional burnout in stress management. SHS Web of Conferences, 28(01132), 1-5. https://doi.org/10.1051/shsconf/20162801132

Maslach, C., Schaufeli, W. B., \& Leiter, M. P. (2001). Job burnout. Annual Review of Psychology, 52(1), $397-422$. https://doi.org/10.1146/annurev.psych.52.1.397

Maroon, I. (2012). Syndrom vyhořeni u sociálních pracovníki̊. Praha: Portál s.r.o. ISBN 978-80-262-0180-9.

Maslach, C., \& Leiter, M. P. (2008). Early predictors of job burnout and engagement. The Journal of Applied Psychology, 93(3), 498-512. https://doi.org/10.1037/0021-9010.93.3.498

Maslach, Christina, \& Leiter, M. P. (2016). Understanding the burnout experience: recent research and its implications for psychiatry. World Psychiatry: Official Journal of the World Psychiatric Association (WPA), 15(2), $103-111$. https://doi.org/10.1016/j.burn.2016.09.001

Mathieu, M., Eschleman, K. J., \& Cheng, D. (2019). Meta-analytic and multiwave comparison of emotional support and instrumental support in the workplace. Journal of Occupational Health Psychology, 24(3), 387-409. https://doi.org/10.1037/ocp0000135

Mazure, C. M., \& Maciejewski, P. K. (2003). The interplay of stress, gender and cognitive style in depressive onset. Archives of Women's Mental Health, 6(1), 5-8. https://doi.org/10.1007/s00737-002-0161-3

Pérez-Fuentes, M. C., Molero, M. M., Gázquez, J. J., \& Soler, F. J. (2015). Estimulación de la Inteligencia Emocional en mayores: El programa PECI-PM. European Journal of Investigation in Health Psychology and Education, 4(3), 329. https://doi.org/10.30552/ejihpe.v4i3.84

Prottas, D. J. (2008). Perceived behavioral integrity: Relationships with employee attitudes, well-being, and absenteeism. Journal of Business Ethics, 81(2), 313-322. https://doi.org/10.1007/s10551-007-9496-z

Ruisoto, P., Ramírez, M. R., García, P. A., Paladines-Costa, B., Vaca, S. L., \& Clemente-Suárez, V. J. (2021). Social support mediates the effect of burnout on health in health care professionals. Frontiers in Psychology, 11, 623587. https://doi.org/10.3389/fpsyg.2020.623587

Salazar, I. C., Roldán, G. M., \& Garrido, L. (2014). La asertividad y su relación con los problemas emocionales y el desgaste en profesionales sanitarios [Assertiveness and its relationship to emotional problems and burnout in healthcare $\begin{array}{llrlrl}\text { workers.]. Behavioral } & \text { Psychology/Psicología } & \text { Conductual, 22(3), } & 523-549 . & \text { Retrieved } & \text { from }\end{array}$ https://www.behavioralpsycho.com/wp-content/uploads/2019/08/08.Salazar_22-3oa-1.pdf

Schub, T. (2018). Job Stress and Burnout in Nurses. Retrieved from https://www.ebsco.com/sites/g/files/ nabnos191/files/acquiadam-assets/Nursing-Reference-Center-Plus-Job-Stress-Burnout-in-Nurses-Care-Sheet.pdf

Scott, E. (2020). How to watch for signs of burnout in your life. Retrieved from https://www.verywellmind.com/stress-andburnout-symptoms-and-causes-3144516

Semmer, N., McGrath, J., \& Beehr, T. (2005). Conceptual issues in research on stress and health. In Handbook of Stress Medicine and Health, Second Edition (pp. 1-43). CRC Press.

Schaufeli, W. B., Bakker, A. B., Hoogduin, K., Schaap, C., \& Kladler, A. (2001). On the clinical validity of the maslach burnout inventory and the burnout measure. Psychology \& Health, 16(5), 565-582. https://doi.org/10.1080/08870440108405527

Schaufeli, W. B., Leiter, M. P., \& Maslach, C. (2009). Burnout: 35 years of research and practice. Career Development International, 14(3), 204-220. https://doi.org/10.1108/13620430910966406

Shanafelt, T. D., \& Noseworthy, J. H. (2017). Executive leadership and physician well-being: Nine organizational strategies to promote engagement and reduce burnout. Mayo Clinic Proceedings. Mayo Clinic, 92(1), $129-146$. https://doi.org/10.1016/j.mayocp.2016.10.004

Skinner, E. A., Edge, K., Altman, J., \& Sherwood, H. (2003). Searching for the structure of coping: a review and critique of category systems for classifying ways of coping. Psychological Bulletin, 129(2), 216-269. https://doi.org/10.1037/00332909.129.2.216

Smith, M. (2020). Burnout prevention and treatment. HelpGuide.Org. Retrieved from https://www.helpguide.org/articles/stress/burnout-prevention-and-recovery.htm

Theorell, T., Emdad, R., Arnetz, B., \& Weingarten, A. M. (2001). Employee effects of an educational program for managers at an insurance company. Psychosomatic Medicine, 63(5), 724-733. https://doi.org/10.1097/00006842-200109000-00004

Theorell, T., Hammarström, A., Gustafsson, P. E., Magnusson Hanson, L., Janlert, U., \& Westerlund, H. (2014). Job strain anddepressive symptoms in men and women: a prospective study of the working population in Sweden. Journal of Epidemiology and Community Health, 68(1), 78-82. https://doi.org/10.1136/jech-2012-202294

Useche, S. A., Montoro, L. V., Ruiz, J. I., Vanegas, C., Sanmartin, J., \& Alfaro, E. (2019). Workplace burnout and health issues among Colombian correctional officers. PloS One, 14(2), e0211447. https://doi.org/10.1371/journal.pone.0211447

Velando-Soriano, A., Ortega-Campos, E., Gómez-Urquiza, J. L., Ramírez-Baena, L., De La Fuente, E. I., \& Cañadas-De La Fuente, G. A. (2020). Impact of social support in preventing burnout syndrome in nurses: A systematic review. Japan Journal of Nursing Science: JJNS, 17(1), e12269. https://doi.org/10.1111/jjns.12269 
Vitková, M., \& Zábrodská, K. (2014). Coping a rezistencia voči mobbingu v kontexte paradigmatického prístupu [Coping and resistance to mobbing in the context of paradigmatic approach.]. Československá Psychologie, 58(3), 254-269. ISSN 0009-062X.

Voitenko, E., Kaposloz, H., Myronets, S., Zazymko, O., \& Vasyll, O. E. (2021). Influence of characteristics of self-actualization and coping behavior on resistance of teachers to professional stressors and emotional burnout. International Journal of Organizational Leadership, 10(1), 1-14. https://doi.org/10.33844/ijol.2021.60514

Wharton, A. (2013). Gender and work [Data set]. In Oxford Bibliographies Online Datasets. Oxford University Press (OUP). https://doi.org/10.1093/obo/9780199756384-0127

Wilkie, D. (2020). What managers can do to ease workplace stress. Human Resource Management (SHRM). Retrieved from https://www.shrm.org/resourcesandtools/hr-topics/employee-relations/pages/how-managers-can-help-stressed-workers-.aspx

Yagil, D. (2006). The relationship of abusive and supportive workplace supervision to employee burnout and upward influence tactics. Journal of Emotional Abuse, 6(1), 49-65. https://doi.org/10.1300/j135v06n01_03 